\title{
Teknik Supervisi Individual Untuk Meningkatkan Kemampuan Guru Mata Pelajaran Fisika di SMA
}

\author{
Iceu Rufiana ${ }^{1}$
}

${ }^{1}$ Dinas Pendidikan Sudin Dikmen Kota Administrasi Jakarta Selatan

\begin{tabular}{l} 
ARTICLE INFO \\
\hline Article History: \\
Received 07.02.2018 \\
Received in revised \\
form 14.03.2018 \\
Accepted 30.03 .2018 \\
Available online \\
12.04.2018
\end{tabular}

\begin{abstract}
The aim of this study is to know how the process of implementation of supervision techniques individual for teacher in academic supervision and improve the ability of physics teachers in the implementation of the learning process. Physics teachers who are subjects of science interest in high school still experience some obstacles in the implementation of learning. In general, the problem covers: the understanding of the Minister of National Education Regulation No. 65 of 2013 on Process Standards of Education by both teachers and principals is not evenly distributed; the implementation of academic supervision by the principal is often done just to meet the administrative demands, especially before the accreditation of schools. Based on these problems, then research on academic supervision with individual meeting supervision techniques is very important to be implemented, given the ability of teachers in the learning process is still problematic. Based on the results of the study, academic supervision with individual supervision techniques is able to competency of Physics teachers in high school (SMA).
\end{abstract}

Keywords:

Academic Supervision, Individual Supervision Technique, Physics Teacher.

DOI: $10.30653 / 003.201841 .40$

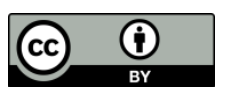

This is an open access article distributed under the terms of the Creative Commons Attribution 4.0 International License, which permits unrestricted use, distribution, and reproduction in any medium, provided the original work is properly cited. (๑) 2018 Iceu Rufiana.

\section{PENDAHULUAN}

Upaya meningkatkan mutu pendidikan memang tidak pernah berhenti, gagasan, hasil penelitian, model, atau pengalaman seputar peningkatan mutu pendidikan senantiasa mengalir kepada komunitas pendidikan. Kondisi ini merupakan suatu indikasi bahwa semangat untuk meningkatkan mutu pendidikan sangatlah besar. Tujuan pendidikan yang dituangkan dalam Undang-Undang No. 20, Tahun 2003. Pasal 3 menyebutkan, "Pendidikan Nasional berfungsi mengembangkan kemampuan dan membentuk watak serta peradaban bangsa yang bermartabat dalam rangka mencerdaskan kehidupan bangsa, bertujuan untuk berkembangnya potensi peserta didik agar menjadi manusia yang beriman dan bertakwa kepada Tuhan Yang Maha Esa, berakhlak mulia, sehat, berilmu, cakap, kreatif, mandiri, dan menjadi warga negara yang demokratis serta bertanggung jawab."

Untuk mencapai tujuan tersebut telah ditetapkan serangkaian prinsip penyelenggaraan pendidikan untuk dijadikan landasan dalam pelaksanaan reformasi pendidikan. Salah satu prinsip tersebut

${ }^{1}$ Corresponding author's address: Dinas Pendidikan Sudin Dikmen Kota Administrasi Jakarta Selatan e-mail: hegarharini@yahoo.com 
adalah Pendidikan diselenggarakan sebagai proses pembudayaan dan peserta didik yang berlangsung sepanjang hayat. Dalam proses tersebut jelas peran guru sangat dominan dan tak tergantikan oleh apapun. Dalam proses tersebut diperlukan guru yang memberikan keteladanan, membangun kemauan, dan mengembangkan potensi dan . kreativitas peserta didik. Implikasi dari prinsip ini adalah pergeseran paradigma proses pendidikan, yaitu dari paradigma pengajaran ke paradigma pembelajaran. Pembelajaran adalah proses interaksi peserta didik dengan guru dan sumber belajar pada suatu lingkungan belajar. Proses pembelajaran perlu direncanakan, dilaksanakan, dinilai, dan diawasi agar terlaksana secara efektif dan efisien.

Peraturan Menteri Pendidikan Nasional nomor 65 tahun 2013 tentang Standar Proses Pendidikan memberikan panduan dalam penyelenggaraan pembelajaran di kelas. yang meliputi perencanaan, pelaksanaan, dan evaluasi. Perencanaan meliputi silabus dan rencana program pembelajaran (RPP). Dalam pelaksanaa kegiatan pembelajaran meliputi kegiatan pendahuluan, inti, dan penutup. Pada kegiatan pendahuluan hendaknya terlebih dahulu guru mengondisikan peserta didik secara phisik dan psikhis, . mengaitkan dengan materi sebelumnya, menyampaikan kompetensi dasar (KD) atau tujuan pembelajaran, serta menyampaikan ruang lingkup materi yang akan dipelajari. Dalam kegiatan inti mencakup tahapan eksplorasi, elaborasi, dan konfirmasi. Sedangkan dalam kegiatan penutup guru hendaknya membimbing Siswa dalam menyimpulkan peLajaran, melakukan refleksi dan evaluasi, merencanakan kegiatan tindak leiut berdasarkan refleksi tersebut, dan menyampaikan rencana pertemuan berikutnya. Dengan demikian pelaksanaan proses mengajar akan berlangsung secara efektif dan sampai kepada penguasaan kompetensi yang diharapkan sesuai dengan indikator yang ditentukan.

Di beberapa sekolah, masih ditemukan guru guru belum sepenuhnya menerapkan Peraturan Menteri Pendidikan Nasional nomor 65 tahun 2013 khususnya dalam penyusunan RPP dan proses pembelajarannya, sehingga hal ini diduga kuat akan berdampak pada kualitas hasil belajar siswa. Guru mata pelajaran fisika yang merupakan mata pelajaran peminatan IPA di SMA masih mengalami beberapa kendala dalam pelaksanaan pembelajaran. Secara umum permasalahan tersebut melipüti: pemahaman Peraturan Menteri Pendidikan Nasional Nomor 65 tahun 2013 tentang Standar Proses baik oleh guru maupun kepala sekolah belum merata; pelaksanaan supervisi akademik oleh kepala sekolah sering dilakukan sekedar untuk memenuhi tuntutan administrasi terutama menjelang akreditasi sekolah. Berdasarkan kondisi tersebut, maka penulis tertarik untuk melakukan penelitian tindakan sekolah (PTS) dengan judul "Supervisi akademik dengan teknik supervisi individual untuk Meningkatkan Kemampuan Guru mata pelajaran fisika di SMA Negeri 66 Jakarta Selatan, SMA Negeri 109 Jakarta Selatan, dan SMA Negeri 29 Jakarta Selatan dalam melaksanakan proses pembelajaran semester ganjil tahun 2016.

Supervisi ialah suatu aktifitas pembinaan yang direncanakan untuk membantu para guru dan pegawai sekolah lainnya dalam melakukan pekerjaan secara efektif (Purwanto, 2000). Sementara, Manullang (2005) menyatakan bahwa supervisi merupakan proses untuk menerapkan pekerjaan apa yang sudah dilaksanakan, menilainya dan bila perlu mengkoreksi dengan maksud supaya pelaksanaan pekerjaan sesuai dengan rencana semula. Supervisi merupakan usaha memberi pelayanan agar guru menjadi lebih profesional dalam menjalankan tugas melayani peserta didik. Supervisi akademik adalah serangkaian kegiatan membantu guru mengembangkan kemampuannya mengelola proses pembelajaran untuk mencapai tujuan pembelajaran (Daresh, 1992, Glickman et al; 2007). Supervisi akademik tidak terlepas dari penilaian kinerja guru dalam mengelola pembelajaran. Sergiovanni (2007) menegaskan bahwa refleksi praktis penilaian kinerja guru dalam supervisi akademik adalah melihat kondisi nyata kinerja guru untuk menjawab pertanyaan-pertanyaan, misalnya apa yang sebenarnya terjadi di dalam kelas? Apa yang sebenarnya dilakukan oleh guru dan siswa di dalam kelas? Aktivitas-aktivitas mana dari keseluruhan aktivitas di dalam kelas itu yang bermakna bagi guru dan murid?, apa yang telah dilakukan oleh guru dalam mencapai tujuan akademik? Apa kelebihan dan kekurangan guru dan bagaimana cara mengembangkannya?. Berdasarkan jawaban terhadap pertanyaan-pertanyaan ini akan diperoleh informasi mengenai kemampuan guru dalam mengelola pembelajaran. Namun satu 
hal yang perlu ditegaskan di sini, bahwa setelah melakukan penilaian kinerja berarti selesailah pelaksanaan supervisi akademik, melainkan harus dilanjutkan dengan tindak lanjutnya berupa pembuatan program supervisi akademik dan melaksanakannya dengan sebaik-baiknya.

Tujuan supervisi akademik di antaranya adalah membantu guru mengembangkan kompetensinya, mengembangkan kurikulum, mengembangkan kelompok kerja guru, dan membimbing penelitian tindakan kelas (PTK) (Glickman et al; 2007, Sergiovanni, 2007). Supervisi akademik merupakan salah satu fungsi mendasar (essential function) dalam keseluruhan program sekolah (Postman \& Weingartner, 1969; Alfonso et al, 1981; Glickman et al, 2007). Hasil supervisi akademik berfungsi sebagai sumber informasi bagi pengembangan profesionalisme

Teknik supervisi akademik terdiri atas dua macam, yaitu teknik supervisi individual dan teknik supervisi kelompok. Teknik supervisi kelompok adalah satu cara melaksanakan program supervisi yang ditujukan pada dua orang atau lebih. Guru-guru yang diduga, sesuai dengan analisis kebutuhan, memiliki masalah atau kebutuhan atau kelemahan-kelemahan yang sama dikelompokkan atau dikumpulkan menjadi satu/bersama-sama. Kemudian kepada mereka diberikan layanan supervisi sesuai dengan permasalahan atau kebutuhan yang mereka hadapi. Menurut Gwynn (1970), ada tiga belas teknik supervisi kelompok yaitu kepanitiaan-kepanitiaan, kerja kelompok, laboratorium dan kurikulum, membaca terpimpin, demonstrasi pembelajaran, darmawisata, kuliah/studi, diskusi panel, perpustakaan, organisasi profesional, buletin supervisi, pertemuan guru, lokakarya atau konferensi kelompok.

Teknik supervisi individual adalah pelaksanaan supervisi perseorangan terhadap guru. Supervisor di sini hanya berhadapan dengan seorang guru sehingga dari hasil supervisi ini akan diketahui kualitas pembelajarannya. Teknik supervisi individual terdiri atas lima macam yaitu kunjungan kelas, observasi kelas, pertemuan individual, kunjungan antar kelas, dan menilai diri sendiri. Pada penelitian ini difokuskan pada pelaksanaan teknik supervisi individual guna meningkatkan kemampuan guru mata pelajaran fisika di SMA.

\section{METODE}

Penelitian tindakan sekolah (PTS) ini adalah tindakan supervisi akademik dengan teknik pertemuan individual yang dilakukan oleh peneliti dan kolaborator terhadap guru Fisika di SMA Negeri 66 Jakarta Selatan, SMA Negeri 109 Jakarta Selatan, dan SMA Negeri 29 Jakarta Selatan. Waktu penelitian dilaksanakan selama 4 bulan, yaitu pada bulan Agustus, September, Oktober dan November 2016.

\section{Langkah-langkah Penelitian}

Pra penelitian

Pada minggu ke dua bulan Agustus tahun 2016 semester ganjil Tahun Pelajaran 2016, peneliti berencana untuk melakukan supervisi akademik terhadap guru mata pelajaran Fisika pada 3 sekolah binaan: SMA Negeri 66 Jakarta Selatan, SMA Negeri 109 Jakarta Selatan, dan SMA Negeri 29 Jakarta Selatan.

Peneliti merasakan rencana tersebut tidak direspon oleh guru guru, bahkan guru menunjukkan kecenderungan untuk menghindar dengan berbagai macam alasan. Peneliti menggali faktor-faktor yang menjadi penyebab tidak antusiasnya guru menjalani proses supervisi dengan beberapa pertanyaan diantaranya pemahaman guru tentang standar proses, yang tercantum dalam Peraturan Menteri Pendidikan Nasional Nomor 65 tahun 2013. Temyata guru-guru mengungkapkan bahwa permen itu belum sempat dibaca dan keseharian melaksanakan proses pembelajaran seperti biasa seperti tahun-tahun sebeluınnya. Kemudian peneliti menagkap ada perasaan sungkan, kawatir bahkan merasa malu kalau disupervisi.

Berdasarkan temuan tersebut peneliti tertarik untuk melakukan penelitian tindakan dengan melibatkan para kepala sekolah tersebut untuk menjadi kolaborator. Setelah disepakati, maka selanjutnya peneliti merancang penelitian. 
Rancangan penelitian tindakan sekolah dilakukan melalui proses pengamatan dengan menggunakan 2 (dua) siklus. Adapun proses dari siklus yang diilaksanakan dapat digambarkan seperti pada Gambar 1.

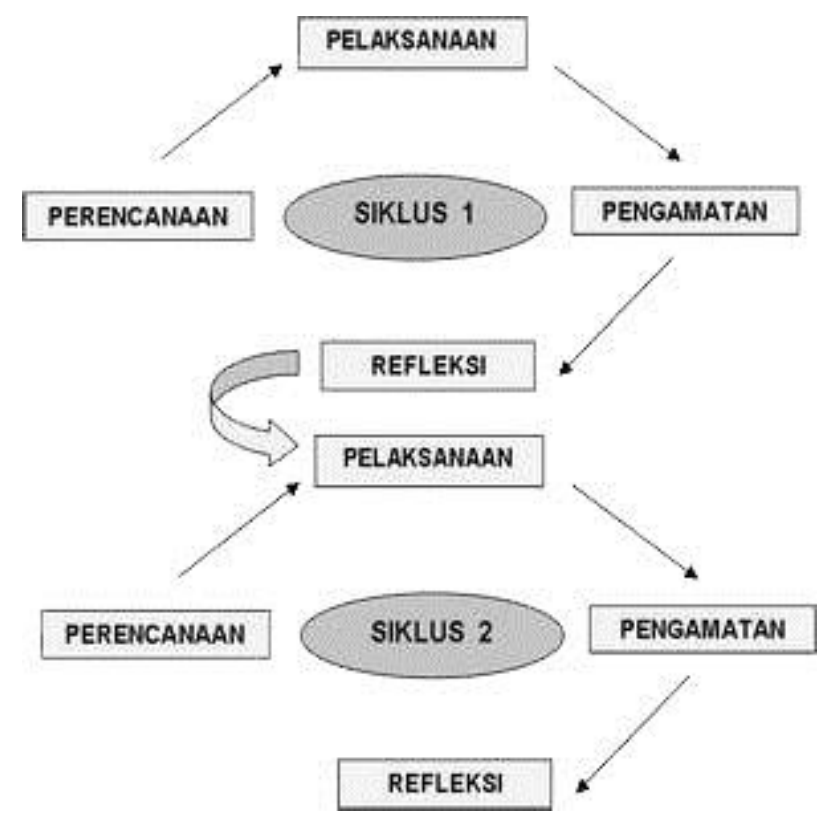

Gambar 1. Siklus Pelaksanaan PTS

Sumber: Riset Aksi Model John Elliot (1991)

Siklus I

Perencanaan: Peneliti menyampaikan tujuan dan manfaat supervisi akademik kepada guru, juga meyakinkan bahwa proses ini tidak perlu ditakutkan tapi sebaliknya harus dimaknai proses guru meningkatkan kemampuan dalam mengelola pembelajaran. Berikutnya peneliti, guru dan kepala sekolah merancang jadwal observasi kelas dan pertemuan individu. Sebelumnya guru juga diminta untuk menyiapakan RPP dan memahami isi permen nomor 65 ttahun 2013. Kemudian peneliti juga nenunjukkan instrument pengamatan proses PBM dan instrument penelaahan RPP. Peneliti, kepala sekolah dan guru mendiskusikan dan mematangkan waktu untuk pengamatan di kelas dan pertemuan individual sebagai bagian inti pada proses supervisi akademik.

Pelaksanaan dan pengamatan: Guru melaksanakan proses pembelajaran sesuai dengan RPP yang disusun pada jam pelajaran sesuai jadwal. Peneliti dan kolaborator bersama-saina mengamati pelaksanaan proses pembelajaran mulai dari pendahuluan, inti dan penutup, dengan menggunakan instrumen yang telah disiapkan. Selama pelaksanaan pengamatan, peneliti dan kolaborator mencermati hal-hal penting yang terjadi dalam proses pembelajaran sebagai dasar untuk membubuhkan nilai kemampuan guru pada instrumen tersebut. Selain membubuhkan nilai, peneliti dan kolaborator juga mencatat hal-hal penting yang terjadi selama proses pembelajaran berlangsung sabagai bahan diskusi saat refleksi.

Setelah peneliti melakukan observasi di kelas dilanjutkan pertemuan individual. Peneliti menyampaikan hal-hal yang sesuai dilakukan guru saat proses pembelajaran. Guru dan mengkonfirmasi hal-hal yang disampaikan peneliti juga menyampaikan kesulitas-kesulitan yang dirasakan guru celaksankan proses pembelajar. Kemudian peneliti memberikan maşukan dan solusi atas hal hal yang tidak sesuai dengan standar proses.

Refleksi: Guru menyampaikan perasaan dan pengalamannya selama melaksanakan proses pembelajaran. Secara bergiliran peneliti dan kolaborator menyampaikan hasil temuannya selama pengamatan pelaksanaan proses pembelajaran. Guru, peneliti, dan kolaborator mendiskusikan hasil pengalaman dan temuan-temuan pada saat pelaksanaan proses pembelajaran sebagai bahan mentukan kegiatan tindak lanjut pada siklus berikutnya 


\section{Siklus II}

Perencanaan: Hasil refleksi siklus I dijadikan bahan untuk menentukan tindakan pada siklus II. Pada perencanaan sjklus ini, guru menyusun kembali RPP yang lebih aplikatif agar pelaksanaan proses pembelajaran lebih efektif. Peneliti bersama guru dan kolaborator menentukan jadwal pelaksanaan pembelajaran dan supervisi akademik sklus II. Peneliti menyiapkan instrumen (sama dengan siklus I) dengan fokus pengamatan pada aspek-aspek yang pada siklus I perlu peningkatan

Pelaksanaan dan pengamatan: Guru melaksanakan proses pembelajaran sesuai dengan jadwal jam mengajar. Peneliti dan kolaborator melaksanakan kunjungan kelas dalam supervisi akademik dengan melakaukan pengamatan pelaksanaan proses pebelajaran berdasarkan instrumen. Penaliti dan kolaboirator mencermati peristiwa yang terjadi selaam proses pembelajaran berlangsung dan membubuhkan nilai pada instrumen tersebut. Peneliti dan kolaborator mencatat temuan-temuan penting sebagai bahan disksusi pada saat refleksi. Setelah melakukan çengamatan di kelas dilanjutkan dengan pertemuan individual. Peneliti menyapaikan hal-hal yang merupakan kemajuan yang dicapai guru juga disampaikan catatan-catatan yang masih harus diperbaiki. Guru menyimak dan menyampaikan kendala kendala yang masih dialami.

Refleksi: Guru mengungkapkan perasaan dan pengalamannya dari mulai pelaksanaan pembelajaran dan setelah proses pertemuan dengan pengawas. Pada siklus ke II, Kolaborator dan peneliti menanggapi ekpresi perasaan guru terutama setelah selesai pertemuan individual, kemuadian peneliti dan kolaborator menyampaikan temuan-temuan selama pelaksanaan pengamatan pada siklus II. Pengalaman guru, pengamatan kolaborator dan peneliti, didiskusikan dijadikan bahan untuk mengambil kesimpulan atas pelaksanaan PTS ini.

\section{Instrumen Penelitian}

PTS ini menggunakan instrumen kunjungan kelas berupa pengamatan pelaksanaan proses pembelajaran berdasarkan Permendikbud Nomor 65 Tahun 2013 tentang Standar Proses. Ada tiga kegiatan penting yang akan diamati dalam proses pelaksasanaan pembelajaran, yairu kegiatan pendahuluan, inti, dan penutup yang tercakup dalam kisi-kisi seperti pada Tabel 1.

Tabel 1. Kisi-kisi Instrumen Kunjungan Kelas

\begin{tabular}{|c|c|c|c|c|c|}
\hline No & Kegiatan & Jml butir & $\begin{array}{l}\text { Skor Tiap } \\
\text { butir }\end{array}$ & Skor maksimal & Keterangan \\
\hline 1 & Pendahuluan & 7 & 1 s.d 5 & 35 & \multirow{4}{*}{$\begin{array}{l}\text { Prestasi kerja } \\
86-100=\text { Amat baik } \\
75-85=\text { Baik } \\
56-74=\text { Cukup } \\
46-55=\text { Kurang } \\
\leq 45=\text { Amat kurang }\end{array}$} \\
\hline 2 & Inti & 27 & 1 s.d 5 & 135 & \\
\hline \multirow[t]{3}{*}{3} & Penutup & 6 & 1 s.d 5 & 30 & \\
\hline & Jumlah & 40 & & 200 & \\
\hline & \multicolumn{5}{|c|}{$=\frac{\text { Total perolehan skor }}{\text { skor maksimal }}$} \\
\hline
\end{tabular}

\section{Jenis dan Teknik Pengelolaan Data}

Jenis data yang diperoleh dalam pengamatan kunjungan kelas berupa data kualitatif yaitu amat baik, baik, cukup, kurang, dan amat kurang. Data kualitatif tersebut kemudian ditabulasikan ke dalam data kuantitatif dengan skala likert: amat baik 5; baik 4; cukup 3; kurang 2; amat kurang 1. Jumlah indikator dalam kegiatan pendahuluan ada 3 butir dengan skor maksimal $(7 \times 5)=35$; kegiatan inti ada 27 indikator dengan skor maksimal $(27 \times 5)=135$; dan kegiatan penutup ada 6 indikator dengan skor maksimal $(6 \times 5)=30$. Skor yang diperoleh adalah jumlah indikator $x$ skor, kemudian seluruh skor dijumlahkan. Nilai akhir diperoleh dari (jumlah skor yang diperoleh dibagi jumlah skor maksimal) kali 100. Nilai akhir inilah yang selanjutnya dijadikan dasar untuk mengambil kesimpulan.

\section{Indikator Keberhasilan}

PTS ini dikatakan berhasil apabila tindakan yang dilakukan dapat meningkatkan kualitas kemampuan guru dalam melaksanakan kegiatan, proses pembelajaran dengan indikator 
keberhasilan: 1) kualitas kemampuan guru dalam pelaksanaan proses pembelajaran, Amat Baik (A) : jika nilai akhir yang diperoleh antara 86 s.d 100; 2) kualitas kemampuan guru dalam kualitas kemampuan guru dalam pelaksanaan proses pembelajaran Baik (B): jika nilai akhir yang peroleh antara 76 s.d 85;3) kualitas kemampuan guru dalam kualitas kemampuan guru dalam pelaksanaan proses pembelajaran Cukup (C): jika nilai akhir yang peroleh antara 56 s.d 75; 4) kualitas kemampuan guru dalam kualitas kemampuan guru dalam pelaksanaan proses pembelajaran Kurang (D): jika nilai akhir yang peroleh antara 46 s.d 55; 5) kualitas kemampuan guru dalam kualitas kemampuan guru dalam pelaksanaan proses pembelajaran Amat Kurang (E): jika nilai akhir yang peroleh lebih kecil atau sama dengan 45 .

\section{HASIL DAN PEMBAHASAN}

Sebelum dimulai siklus 1 peneliti menyampaikan rangkaian aktivitas yang akan dilakukan pada setiap siklusnya, peneliti juga berkesempatan untuk berdiskusi agar kegiatan dapat difahami dengan benar. Penelitian siklus I dilaksanakan sesuai jadwal yaitu pada hari Senin tanggal 5 Agustus 2016 di SMA Negeri 66 Jaksel, pada hari Selasa tanggal 6 Agustus 2016 di SMA Negeri 109 Jaksel dan pada hari Kamis tanggal 8 Agustus 2016 di SMA Negeri 29 Jaksel. Kegiatan dimulai dengan melakukan pengamatan di kelas oleh peneliti dan kolaburator kemudian dilajutkan dengan pertemuan individu, Sedangkan siklus II dilaksanakan hal yang sama seperti di siklus I yaitu pada hari Senin tanggal 10 September 2016 di SMA Negeri 66 Jaksel, pada hari Selasa tanggal 11 September 2016 di SMA Negeri 109 Jaksel dan pada hari Kamis tanggal 13 September 2016 di SMA Negeri 29 Jaksel.

Sebelum melakukan kunjungan kelas terlebih dahulu peneliti melakukan pertemuan awal dengan guru dan kolaburator untuk mendiskusikan aspek-aspek yang akan diamati. Setelah dipahami oleh pihak, maka berlanjut dengan proses pelaksanaan/pengamatan pembelajaran dikelas. Setelah proses pelaksanaan/ pengamatan pembelajaran dikelas maka dilakukan kegiatan pertemuan individual yang merupakan kegiatan inti dari penelitian ini.

Siklus I

Hasil pelaksanaan/pengamatan yang dilakukan pada pelaksanaan pembelajaran dikelas oleh guru fisika seperti dicantumkan pada Tabel 2, Tabel 3, Tabel 4, dan Tabel 5.

Tabel 2. Hasil Pengamatan terhadap guru fisika SMAN 66 Jaksel

\begin{tabular}{|c|c|c|c|c|c|c|}
\hline No & Kegiatan & Sumber Data & Skor & Jumlah & Rata-rata & Nilai Akhir \\
\hline \multirow{2}{*}{1} & \multirow{2}{*}{ Pendahuluan } & Peneliti & 24 & \multirow{2}{*}{46} & \multirow{2}{*}{23.0} & \multirow{6}{*}{64.5} \\
\hline & & Kolaburator & 24 & & & \\
\hline \multirow{2}{*}{2} & \multirow{2}{*}{ Inti } & Peneliti & 85 & \multirow{2}{*}{173} & \multirow{2}{*}{86.5} & \\
\hline & & Kolaburator & 88 & & & \\
\hline \multirow{3}{*}{3} & \multirow{2}{*}{ Penutup } & Peneliti & 19 & \multirow{2}{*}{39} & \multirow{2}{*}{19.5} & \\
\hline & & Kolaburator & 20 & & & \\
\hline & & Jumlah & & & 129 & \\
\hline
\end{tabular}

Tabel 3. Hasil Pengamatan terhadap guru fisika SMAN 109 Jaksel

\begin{tabular}{|c|c|c|c|c|c|c|}
\hline No & Kegiatan & Sumber Data & Skor & Jumlah & Rata-rata & Nilai Akhir \\
\hline \multirow{2}{*}{1} & \multirow{2}{*}{ Pendahuluan } & Peneliti & 22 & \multirow{2}{*}{46} & \multirow{2}{*}{23.0} & \multirow{7}{*}{64.75} \\
\hline & & Kolaburator & 24 & & & \\
\hline \multirow{2}{*}{2} & \multirow{2}{*}{ Inti } & Peneliti & 85 & \multirow{2}{*}{174} & \multirow{2}{*}{87.0} & \\
\hline & & Kolaburator & 89 & & & \\
\hline \multirow{3}{*}{3} & \multirow{2}{*}{ Penutup } & Peneliti & 19 & \multirow{2}{*}{39} & \multirow{2}{*}{19.5} & \\
\hline & & Kolaburator & 20 & & & \\
\hline & & Jumlah & & & 129.5 & \\
\hline
\end{tabular}


Tabel 4. Hasil Pengamatan terhadap guru fisika SMAN 29 Jaksel

\begin{tabular}{|c|c|c|c|c|c|c|}
\hline No & Kegiatan & Sumber Data & Skor & Jumlah & Rata-rata & Nilai Akhir \\
\hline \multirow{2}{*}{1} & \multirow{2}{*}{ Pendahuluan } & Peneliti & 23 & \multirow{2}{*}{47} & \multirow{2}{*}{23.5} & \multirow{6}{*}{64.5} \\
\hline & & Kolaburator & 24 & & & \\
\hline \multirow{2}{*}{2} & \multirow{2}{*}{ Inti } & Peneliti & 84 & \multirow{2}{*}{172} & \multirow{2}{*}{86.0} & \\
\hline & & Kolaburator & 88 & & & \\
\hline \multirow{3}{*}{3} & \multirow{2}{*}{ Penutup } & Peneliti & 19 & \multirow{2}{*}{39} & \multirow{2}{*}{19.5} & \\
\hline & & Kolaburator & 20 & & & \\
\hline & & Jumlah & & & 129 & \\
\hline
\end{tabular}

Tabel 5. Rekapitulasi hasil pengamatan guru fisika Masing-masing Sekolah

\begin{tabular}{|c|c|c|c|c|c|}
\hline No & Sekolah & Kegiatan & Skor rata-rata & Jml Skor & Nilai Akhir \\
\hline \multirow{3}{*}{1} & \multirow{3}{*}{ SMAN 66 Jaksel } & Pendahuluan & 23.0 & \multirow{3}{*}{129.0} & \multirow{3}{*}{64.5} \\
\hline & & Inti & 86.5 & & \\
\hline & & Penutup & 19.5 & & \\
\hline \multirow{3}{*}{2} & \multirow{3}{*}{ SMAN 109 Jaksel } & Pendahuluan & 23.0 & \multirow{3}{*}{129.5} & \multirow{3}{*}{64.75} \\
\hline & & Inti & 87.0 & & \\
\hline & & Penutup & 19.5 & & \\
\hline \multirow{3}{*}{3} & \multirow{3}{*}{ SMAN 29 Jaksel } & Pendahuluan & 23.5 & \multirow{3}{*}{129.0} & \multirow{3}{*}{64.5} \\
\hline & & Inti & 86.0 & & \\
\hline & & Penutup & 19.5 & & \\
\hline
\end{tabular}

Siklus II

Hasil pelaksanaan/pengamatan yang dilakukan pada pelaksanaan pembelajaran di kelas oleh guru fisika seperti disajikan pada Tabel 6, Tabel 7, Tabel 8, dan Tabel 9, termasuk rekapitulasi hasil pengamatan Siklus I dan Siklus II pada Tabel 10.

Tabel 6. Hasil Pengamatan terhadap guru fisika SMAN 66 Jaksel

\begin{tabular}{|c|c|c|c|c|c|c|}
\hline No & Kegiatan & Sumber Data & Skor & Jumlah & Rata-rata & Nilai Akhir \\
\hline \multirow{2}{*}{1} & \multirow{2}{*}{ Pendahuluan } & Peneliti & 29 & \multirow{2}{*}{59} & \multirow{2}{*}{29.5} & \multirow{6}{*}{87.75} \\
\hline & & Kolaburator & 30 & & & \\
\hline \multirow{2}{*}{2} & \multirow{2}{*}{ Inti } & Peneliti & 119 & \multirow{2}{*}{239} & \multirow{2}{*}{119.5} & \\
\hline & & Kolaburator & 120 & & & \\
\hline \multirow{3}{*}{3} & \multirow{2}{*}{ Penutup } & Peneliti & 26 & \multirow{2}{*}{53} & \multirow{2}{*}{26.5} & \\
\hline & & Kolaburator & 27 & & & \\
\hline & & Jumlah & & & 175.5 & \\
\hline
\end{tabular}

Tabel 7. Hasil Pengamatan terhadap guru fisika SMAN 109 Jaksel

\begin{tabular}{|c|c|c|c|c|c|c|}
\hline No & Kegiatan & Sumber Data & Skor & Jumlah & Rata-rata & Nilai Akhir \\
\hline \multirow{2}{*}{1} & \multirow{2}{*}{ Pendahuluan } & Peneliti & 31 & \multirow{2}{*}{63} & \multirow{2}{*}{31.5} & \multirow{6}{*}{87.5} \\
\hline & & Kolaburator & 32 & & & \\
\hline \multirow{2}{*}{2} & \multirow{2}{*}{ Inti } & Peneliti & 115 & \multirow{2}{*}{233} & \multirow{2}{*}{116.5} & \\
\hline & & Kolaburator & 118 & & & \\
\hline \multirow{3}{*}{3} & \multirow{3}{*}{ Penutup } & Peneliti & 26 & \multirow{2}{*}{54} & \multirow{2}{*}{27} & \\
\hline & & Kolaburator & 28 & & & \\
\hline & & Jumlah & & & 175.0 & \\
\hline
\end{tabular}


Tabel 8. Hasil Pengamatan terhadap guru fisika SMAN 29 Jaksel

\begin{tabular}{|c|c|c|c|c|c|c|}
\hline No & Kegiatan & Sumber Data & Skor & Jumlah & Rata-rata & Nilai Akhir \\
\hline \multirow{2}{*}{1} & \multirow{2}{*}{ Pendahuluan } & Peneliti & 30 & \multirow{2}{*}{60} & \multirow{2}{*}{30} & \multirow{6}{*}{88.25} \\
\hline & & Kolaburator & 30 & & & \\
\hline \multirow{2}{*}{2} & \multirow{2}{*}{ Inti } & Peneliti & 118 & \multirow{2}{*}{239} & \multirow{2}{*}{119.5} & \\
\hline & & Kolaburator & 121 & & & \\
\hline \multirow{3}{*}{3} & \multirow{2}{*}{ Penutup } & Peneliti & 27 & \multirow{2}{*}{54} & \multirow{2}{*}{27} & \\
\hline & & Kolaburator & 27 & & & \\
\hline & & Jumlah & & & 176.5 & \\
\hline
\end{tabular}

Tabel 9. Rekapitulasi hasil pengamatan guru fisika SMAN 66, SMAN 109, dan SMAN 29 Jaksel

\begin{tabular}{|c|c|c|c|c|c|}
\hline No & Sekolah & Kegiatan & Skor rata-rata & Jml Skor & Nilai Akhir \\
\hline \multirow{3}{*}{1} & \multirow{3}{*}{ SMAN 66 Jaksel } & Pendahuluan & 29.5 & \multirow{3}{*}{175.5} & \multirow{3}{*}{87.75} \\
\hline & & Inti & 119.5 & & \\
\hline & & Penutup & 26.5 & & \\
\hline \multirow{3}{*}{2} & \multirow{3}{*}{ SMAN 109 Jaksel } & Pendahuluan & 31.5 & \multirow{3}{*}{175.0} & \multirow{3}{*}{87.5} \\
\hline & & Inti & 116.5 & & \\
\hline & & Penutup & 27.0 & & \\
\hline \multirow{3}{*}{3} & \multirow{3}{*}{ SMAN 29 Jaksel } & Pendahuluan & 30.0 & \multirow{3}{*}{176.5} & \multirow{3}{*}{88.25} \\
\hline & & Inti & 119.5 & & \\
\hline & & Penutup & 27.0 & & \\
\hline
\end{tabular}

Tabel 10. Rekapitulasi Hasil pengamatan Siklus I dan Siklus II

\begin{tabular}{|c|c|c|c|c|c|c|}
\hline \multirow{2}{*}{ No } & \multirow{2}{*}{ Sekolah } & \multirow{2}{*}{ Kegiatan } & \multicolumn{2}{|c|}{ Skor rata-rata } & \multicolumn{2}{|c|}{ Nilai Akhir } \\
\hline & & & Siklus I & Siklus II & Siklus I & Siklus II \\
\hline \multirow{3}{*}{1} & \multirow{3}{*}{ SMAN 66 Jaksel } & Pendahuluan & 23 & 29.5 & \multirow{3}{*}{64.5} & \multirow{3}{*}{87.75} \\
\hline & & Inti & 86.5 & 119.5 & & \\
\hline & & Penutup & 19.5 & 26.5 & & \\
\hline \multirow{3}{*}{2} & \multirow{3}{*}{ SMAN 109 Jaksel } & Pendahuluan & 23.0 & 31.5 & \multirow{3}{*}{64.75} & \multirow{3}{*}{87.5} \\
\hline & & Inti & 87.0 & 116.5 & & \\
\hline & & Penutup & 19.5 & 27.0 & & \\
\hline \multirow{3}{*}{3} & \multirow{3}{*}{ SMAN 29 Jaksel } & Pendahuluan & 23.5 & 30.0 & \multirow{3}{*}{64.5} & \multirow{3}{*}{88.25} \\
\hline & & Inti & 86.0 & 119.5 & & \\
\hline & & Penutup & 19.5 & 27.0 & & \\
\hline
\end{tabular}

Hasil pengamatan yang dilakukan oleh peneliti maupun observer pada guru fisika di SMAN 66, SMAN 109 dan SMAN 29 Jaksel menunjukkan hasil sebagai berikut

\section{Kegiatan Pendahuluan}

Pertama, untuk SMAN 66 Jaksel, terjadi perubahan pada butir 2 dan butir 4, yaitu menyampaikan rencana kegiatan dan menyampaikan manfaat materi pembelajaran. Pada butir 2 dan butir 4 terjadi perubahan proses pembelajaran yang signifikan, dari kriteria cukup dan baik untuk butir tersebut di siklus I berubah menjadi kriteria amat baik di siklus II. Ini menunjukkan guru. Secara umum pada kegiatan pendahuan yang terdiri dari 7 indikator, pencapaian kinerjanya terjadi peningkatan, dari kriteria cukup (3) dan baik (4) menjadi kriteria amat baik (5) ini menunjukkan kegiatan Teknik pendampingan individual dapat meningkatkan kempuan guru fisika di SMAN 66 Jakarta Selatan dalam penyampaian materi pada kegiatan pendahuluan.

Kedua, untuk SMAN 109 Jaksel, terjadi perubahan pada butir 2, butir 4, butir 6 dan butir 7, yaitu menyampaikan rencana kegiatan, menyampaikan manfaat materi pembelajaran, mengaitkan materi dengan materi sebelumnya dan mendemontrasikan sesuatu yang terkait dengan mata pelajaran 
sebelumnya. Pada butir 2, butir 4, butir 6 dan butir 7 terjadi perubahan proses pembelajaran yang signifikan, dari kriteria cukup dan baik untuk butir tersebut di siklus I berubah menjadi kriteria amat baik di siklus II. Ini menunjukkan guru. Secara umum pada kegiatan pendahuan yang terdiri dari 7 indikator, pencapaian kinerjanya terjadi peningkatan, dari kriteria cukup (3) dan baik (4) menjadi kriteria amat baik (5) ini menunjukkan kegiatan Teknik pendampingan individual dapat meningkatkan kempuan guru fisika di SMAN 109 Jakarta Selatan dalam penyampaian materi pada kegiatan pendahuluan.

Kedua, untuk SMAN 29 Jaksel, terjadi perubahan pada butir 2, butir 3, butir 5 dan butir 6, yaitu menyampaikan rencana kegiatan, mengajukan pertanyaan yang memotivasi, menyampaikan kompetensi yang akan dicapai dan mengaitkan materi dengan materi sebelumnya . Pada butir 2 butir 3, butir 5 dan butir 6, terjadi perubahan proses pembelajaran yang signifikan, dari kriteria cukup dan baik untuk butir tersebut di siklus I berubah menjadi kriteria amat baik di siklus II. Ini menunjukkan guru. Secara umum pada kegiatan pendahuan yang terdiri dari 7 indikator, pencapaian kinerjanya terjadi peningkatan, dari kriteria cukup (3) dan baik (4) menjadi kriteria amat baik (5) ini menunjukkan kegiatan Teknik pendampingan individual dapat meningkatkan kempuan guru fisika di SMAN 29 Jakarta Selatan (Jaksel) dalam penyampaian materi pada kegiatan pendahuluan.

\section{Kegiatan Inti}

Pertama, untuk SMAN 66 Jaksel, terjadi perubahan pada butir 1, butir 5, butir 8, butir 9, butir 11, butir 13 , butir 16, butir 19, butir 21, butir 23, butir 25, butir 26 dan butir 27, yaitu menyesuaikan diri dengan tujuan pembelajaran, melaksanakan pembelajaran sesuai dengan kompetensi yang akan diajarkan, melaksanakan pembelajaran yang mengembangkan keterampilan peserta didik sesuai dengan materi ajar, melaksanakan pembelajaran yang bersifat kontekstual, melaksanakan pembelajaran sesuai dengan alokasi waktu yang direncanakan, memfasilitasi peserta didik untuk bertanya, memfasilitasi kegiatan peserta didik untuk mengkomunikasikan pengetahuan, melibatkan peserta didik dalam memanfaatkan sumber belajar, menghasilkan pesan yang menarik, merespon positif dengan sikap terbuka terhadap partisipasi peserta didik, menumbuhkan keceriaan pesrta didik dalam belajar, menggunakan Bahasa lisan secara jelas dan benar dan menggunakan bahasa tulis yang baik dan benar. Pada butir 1, butir 5, butir 8 , butir 9, butir 11, butir 13, butir 16, butir 19, butir 21, butir 23, butir 25, butir 26 dan butir 27 terjadi perubahan proses pembelajaran yang signifikan, dari kriteria cukup dan baik untuk butir tersebut di siklus I berubah menjadi kriteria amat baik di siklus II. Ini menunjukkan guru. Secara umum pada kegiatan pendahuan yang terdiri dari 27 indikator, pencapaian kinerjanya terjadi peningkatan, kari kriteria cukup (3) dan baik (4) menjadi kriteria amat baik (5), ini menunjukkan kegiatan Teknik pendampingan individual dapat meningkatkan kempuan guru fisika di SMAN 66 Jakarta Selatan dalam penyampaian materi pada kegiatan inti.

Kedua, untuk SMAN 109 Jaksel, terjadi perubahan pada butir 1, butir 4, butir 6, butir 10, butir 12, butir 16, butir 20, butir 22, butir 23 dan butir 27, yaitu menyesuaikan diri dengan tujuan pembelajaran, menyajikan materi secara sistematis (mudah, sulit, kongkrit ke abstrak), melaksanakan pembelajaran yang menumbuhkan partisipasi aktif peserta didik dalam mengajukan pertanyaan, melaksanakan pembelajaran yang memungkinkan tumbuhnya kebiasaan dan sikap positif (nurturant effect), melaksanakan pembelajaran yang memungkinkan tumbuhnya kebiasaan dan sikap positif (nurturant effect), memfasilitasi kegiatan peserta didik untuk mengkomunikasikan pengetahuan, melibatkan peserta didik dalam pemanfaatan media pembelajar, menumbuhkan partisipasi aktif peserta didik melalui interaksi guru, peserta didik dan sumber belajar, merespon positif dengan sikap terbuka terhadap partisipasi peserta didik, dan menggunakan bahasa tulis yang baik dan benar. Pada butir 1, butir 4, butir 6, butir 10, butir 12, butir 16, butir 20, butir 22, butir 23 dan butir 27 terjadi perubahan proses pembelajaran yang signifikan, dari kriteria cukup dan baik untuk butir tersebut di siklus I berubah menjadi kriteria amat baik di siklus II. Ini menunjukkan secara umum guru pada kegiatan inti yang terdiri dari 27 indikator, pencapaian kinerjanya terjadi peningkatan, kari kriteria cukup (3) dan baik (4) menjadi kriteria amat baik (5) ini menunjukkan 
kegiatan Teknik pendampingan individual dapat meningkatkan kempuan guru fisika di SMAN 109 Jakarta Selatan dalam penyampaian materi pada kegiatan inti.

Ketiga, untuk SMAN 29 Jaksel, terjadi perubahan pada butir 1, butir 4, butir 6, butir 7, butir 10, butir 14, butir 16 , butir 17 , butir 20, butir 21, butir 24 , butir 25 , butir 26 dan butir 27 , yaitu menyesuaikan diri dengan tujuan pembelajaran, menyajikan materi secara sistematis (mudah, sulit, kongkrit ke abstrak), melaksanakan pembelajaran yang menumbuhkan partisipasi aktif dalam mengemukakan pendapat, melaksanakan pembelajaran yang menumbuhkan partisipasi aktif peserta didik dalam mengajukan pertanyaan, memfasilitasi kegiatan peserta didik untuk mengumpulkan informasi (eksperimen untuk menguji/membuktikan hipotesa), melaksanakan pembelajaran yang memungkinkan tumbuhnya kebiasaan dan sikap positif (nurturant effect), menunjukkan keterampilan dalam penggunaan sumber belajar yang bervariasi, memfasilitasi kegiatan peserta didik untuk mengkomunikasikan pengetahuan, melibatkan peserta didik dalam pemanfaatan media pembelajar, menghasilkan pesan yang menarik, menunjukkan hubungan antar pribadi yang kondusif, menumbuhkan keceriaan dan antusiasme peserta didik dalam belajar, menggunakan bahasa lisan secara jelas dan lancar dan menggunakan bahasa tulis yang baik dan benar. Pada butir 1, butir 4, butir 6, butir 7, butir 10, butir 14, butir 16, butir 17, butir 20, butir 21, butir 24, butir 25 , butir 26 dan butir 27 terjadi perubahan proses pembelajaran yang signifikan, dari kriteria cukup dan baik untuk butir tersebut di siklus I berubah menjadi kriteria amat baik di siklus II. Ini menunjukkan secara umum guru pada kegiatan inti yang terdiri dari 27 indikator, pencapaian kinerjanya terjadi peningkatan, kari kriteria cukup (3) dan baik (4) menjadi kriteria amat baik (5) ini menunjukkan kegiatan Teknik pendampingan individual dapat meningkatkan kempuan guru fisika di SMAN 29 Jakarta Selatan dalam penyampaian materi pada kegiatan inti.

\section{Kegiatan Penutup}

Pertama, untuk SMAN 66 Jaksel, terjadi perubahan pada butir 1, butir 4 dan butir 6, yaitu memfasilitasi dan membimbing peserta didik merangkim materi pelajaran, melaksanakan penilaian sikap melalui observasi dan melaksanakan penilaian keterampilan melalui penyajian, praktik, laporan, portofolio. Pada butir 1, butir 4 dan butir 6 terjadi perubahan proses pembelajaran yang signifikan, dari kriteria cukup dan baik untuk butir tersebut di siklus I berubah menjadi kriteria amat baik di siklus II. Ini menunjukkan secara umum pada kegiatan penutup yang terdiri dari 6 indikator, pencapaian kinerjanya terjadi peningkatan, dari kriteria cukup (3) dan baik (4) menjadi kriteria amat baik (5) ini menunjukkan kegiatan teknik pendampingan individual dapat meningkatkan kempuan guru fisika di SMAN 66 Jakarta Selatan dalam penyampaian materi pada kegiatan penutup.

Kedua, untuk SMAN 109 Jaksel, terjadi perubahan pada butir 1, butir 3, butir 4 dan butir 6, yaitu memfasilitasi dan membimbing peserta didik merangkim materi pelajaran, melaksanakan tindaklanjut dengan memberikan arahan kegiatan berikutnya dan tugas perbaikan atau pengayaan secara individua tau kelompok, melaksanakan penilaian sikap melalui observasi dan melaksanakan penilaian keterampilan melalui penyajian, praktik, laporan, portofolio. Pada butir 1, butir 3, butir 4 dan butir 6 terjadi perubahan proses pembelajaran yang signifikan, dari kriteria cukup dan baik untuk butir tersebut di siklus I berubah menjadi kriteria amat baik di siklus II. Ini menunjukkan secara umum pada kegiatan penutup yang terdiri dari 6 indikator, pencapaian kinerjanya terjadi peningkatan, dari kriteria cukup (3) dan baik (4) menjadi kriteria amat baik (5) ini menunjukkan kegiatan teknik pendampingan individual dapat meningkatkan kempuan guru fisika di SMAN 109 Jakarta Selatan dalam penyampaian materi pada kegiatan penutup.

Ketiga, untuk SMAN 29 Jaksel, terjadi perubahan pada butir 1, butir 4 dan butir 6, yaitu memfasilitasi dan membimbing peserta didik merangkim materi pelajaran, melaksanakan penilaian sikap melalui observasi dan melaksanakan penilaian keterampilan melalui penyajian, praktik, laporan, portofolio. Pada butir 1, butir 4 dan butir 6 terjadi perubahan proses pembelajaran yang signifikan, dari kriteria cukup dan baik untuk butir tersebut di siklus I berubah menjadi kriteria amat baik di siklus II. Ini menunjukkan secara umum pada kegiatan penutup yang terdiri dari 6 indikator, pencapaian kinerjanya terjadi peningkatan, dari kriteria cukup (3) dan baik (4) menjadi kriteria amat baik (5) ini 
menunjukkan kegiatan teknik pendampingan individual dapat meningkatkan kempuan guru fisika di SMAN 29 Jakarta Selatan dalam penyampaian materi pada kegiatan penutup.

\section{Peningkatan prestasi kerja}

Pada kegiatan pendahuluan, prestasi kerja guru SMAN 109 menunjukkan peningkatan yang paling besar, yaitu 8.50 poin (dari poin 23 menjadi 31,5). Untuk SMAN 66 (dari 23 menjadi 29.5) dan SMAN 29 (dari 23.5 menjadi 30.0) menunjukkan jumlah peningkatan yang sama yaitu 6.50

Pada kegiatan inti prestasi kerja guru SMAN 29 menunjukkan peningkatan yang paling besar, yaitu 33.5 poin (dari poin 86 menjadi 119,5), di ikuti oleh SMAN 66 sebesar 33 poin (dari 86.5 menjadi 119.5) dan selanjutnya yang paling kecil adalah SMAN 109 sebesar 29.5 (dari 87 menjadi 116.5).

Pada kegiatan penutupan prestasi kerja guru SMAN 109 (dari poin 19.5 menjadi 27) menunjukkan peningkatan yang sama dengan SMAN 29 (dari poin 19.5 menjadi 27) yaitu 7.5 poin selanjutnya yang paling kecil adalah SMAN 66 sebesar 7.0 (dari 19.5 menjadi 26.5).

Untuk keseluruhan peningkatan prestasi kerja yang tertinggi adalah SMAN 29 (dari 64.5 menjadi 88.25) sebesar 23.75, selanjutnya SMAN 66 (dari 64.5 menjadi 87.75 ) sebesar 23.25 dan yang terakhir adalah SMAN 109 (dari 64.75 menjadi 87.5) sebesar 22.75 poin.

\section{SIMPULAN}

Supervisi akademik dengan teknik pertemuan individual yang didahului dengan pengamatan proses pembelajaran di kelas sangat sederhana, mudah dilakukan dan memberi ruang yang luas kepada guru untuk berdiskusi dengan peneliti dan kolaborator secara nyaman.

Supervisi akademik dengan Teknik pertemuan individual dapat meningkatkan kemampuan guru Fisika secara signifikan, dilihat dari peningkatan prestasi kerja guru. Dengan demikian, dalam tindak lanjut supervisi dapat disimpulkan sebagai berikut: 1) Dalam pelaksanaannya kegiatan tindak lanjut supervisi akademik sasaran utamanya adalah kegiatan belajar mengajar; 2) Hasil analisis, catatan supervisor, dapat dimanfaatkan untuk perkembangan keterampilan mengajar guru atau meningkatkan profesionalisme guru dan karyawan, setidak-tidaknya dapat mengurangi kendala-kendala yang muncul atau yang mungkin akan muncul; 3) Umpan balik akan member prtolongan bagi supervisor dalam melaksanakan tindak lanjut supervisi; 4) Dari umpan balik itu pula dapat tercipta suasana komunikasi yang tidak menimbulkan ketegangan, menonjolkan otoritas yang mereka miliki, memberi kesempatan untuk mendorong guru memperbaiki penampilan, serta kinerjanya.

Cara-cara melaksanakan tindak lanjut hasil supervisi akademik sebagai berikut: 1) Mengkaji rangkuman hasil penilaian; 2) Apabila ternyata tujuan supervisi akademik dan standar-standar pembelajaran belum tercapai, maka sebaiknya dilakukan penilaian ulang terhadap pengetahuan, keterampilan dan sikap guru yang menjadi tujuan pembinaan.

\section{REFERENSI}

Alfonso, R. J., Firth, G. R., \& Neville, R. F. (1981). Instructional supervision: A behavior system. Boston: Allyn \& Bacon.

Daresh, J. (1992). In search of a knowledge base to guide program development in educational leadership. Journal of School Leadership, 2(4), 429-42.

Elliot, J. (1991). Action research for educational change. London: McGraw-Hill Education.

Glickman, C. D., Gordon, S. P., \& Ross-Gordon, J. M. (2007). Supervision and instructional leadership: A developmental approach (7th ed.). Boston: Pearson.

Gwynn, J. M. (1970). Theory and practice of supervision. New York: Dodd, Mead \& Co.

Manullang. (2005). Dasar-dasar Manajemen. Yogyakarta: UGM Press.

Peraturan Menteri Pendidikan Nasional nomor 65 tahun 2013 tentang Standar Proses Pendidikan. 
Postman, N., \& Weingartner, C. (1969). Teaching as a Subversive Activity. New York: Dell Publishing Company.

Purwanto, N. (2000). Administrasi dan Supervisi Pendidikan. Bandung: Rosda Karya.

Sergiovanni, T. J. (2007). Rethinking leadership: A collection of articles. Thousand Oaks, CA: Corwin Press.

Undang-undang No. 20, Tahun 2003 Tentang Sistem Pendidikan Nasional. 